\title{
miR-291b-3p mediated ROS-induced endothelial cell dysfunction by targeting HUR
}

\author{
XIAOFANG SUI $^{1 *}$, SHUQIAN YU $^{1 *}$, LIN DOU $^{2 *}$, XIEHUI CHEN $^{3 *}$, XUEJIE LI $^{4}$,

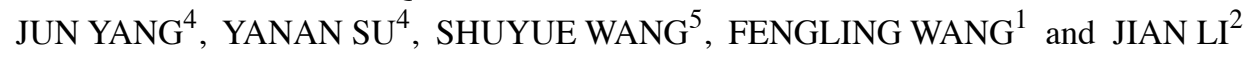 \\ ${ }^{1}$ Department of Geriatrics, The First Affiliated Hospital of Jiamusi University, Jiamusi, Heilongjiang 154002; \\ ${ }^{2}$ The Ministry of Health Key Laboratory of Geriatrics, Beijing Hospital, National Center of Gerontology, Beijing 100730; \\ ${ }^{3}$ Department of Geriatric Cardiovascular Medicine, Shenzhen Sun Yat-Sen Cardiovascular Hospital, Shenzhen, \\ Guangdong 518112; ${ }^{4}$ Department of Geriatrics, Clinical Medical School, Jiamusi University, Jiamusi, \\ Heilongjiang 154002; ${ }^{5}$ National Engineering Laboratory for Druggable Gene and Protein Screening, \\ Northeast Normal University, Changchun, Jilin, P.R. China
}

Received April 9, 2018; Accepted August 6, 2018

DOI: 10.3892/ijmm.2018.3821

\begin{abstract}
Endothelial dysfunction is an early marker of atherosclerosis. Previous studies have indicated that microRNA (miR)-291b-3p regulates the metabolism of lipids and glucose in the liver via targeting adenosine monophosphate-activated kinase $\alpha 1$ and transcription factor p65. The present study investigated whether miR-291b-3p mediated $\mathrm{H}_{2} \mathrm{O}_{2}$-mediated endothelial dysfunction. The level of apoptosis of EOMA mouse endothelial cells was analyzed by terminal deoxynucleotidyl-transferase-mediated dUTP nick end labelling staining. The mRNA levels of miR-291b-3p, intercellular adhesion molecule-1 (ICAM-1) and vascular adhesion molecule-1 (VCAM-1) were determined by quantitative polymerase chain reaction. The level of phosphorylated extracellular signal-regulated kinase, and levels of B-cell lymphoma 2 (Bcl-2)-associated $\mathrm{X}$ protein and $\mathrm{Bcl}-2$ protein were detected by western blot analysis. The treatment of $\mathrm{H}_{2} \mathrm{O}_{2}$ induced the apoptosis and increased the mRNA levels of miR-291b-3p, ICAM-1 and VCAM-1 in EOMA cells. It was also demonstrated that the overexpression of miR-291b-3p promoted EOMA cell apoptosis and dysfunction. In contrast,
\end{abstract}

Correspondence to: Dr Fengling Wang, Department of Geriatrics, The First Affiliated Hospital of Jiamusi University, 348 Dexiang Road, Jiamusi, Heilongjiang 154002, P.R. China

E-mail: fucongtianjiang@163.com

Dr Jian Li, The Ministry of Health Key Laboratory of Geriatrics, Beijing Hospital, National Center of Gerontology, 1 Dahua Road, Beijing 100730, P.R. China

E-mail: lijian@bjhmoh.cn

${ }^{*}$ Contributed equally

Key words: microRNA-291b-3p, apoptosis, Hu antigen $\mathrm{R}$, intercellular adhesion molecule-1, vascular cell adhesion molecule-1 the downregulation of miR-291b-3p rescued the effect of $\mathrm{H}_{2} \mathrm{O}_{2}$ on EOMA cell dysfunction. In addition, $\mathrm{Hu}$ antigen $\mathrm{R}$ (HuR) was identified as a target gene of miR-291b-3p in EOMA cells. The overexpression of HuR reversed the endothelial dysfunction induced by miR-291b-3p mimics. The present study provides novel insight into the critical role of miR-291b-3p on the endothelial dysfunction induced by $\mathrm{H}_{2} \mathrm{O}_{2}$. miR-291b-3p may mediate $\mathrm{H}_{2} \mathrm{O}_{2}$-induced endothelial dysfunction via targeting HuR.

\section{Introduction}

Atherosclerosis is a chronic inflammatory disease of the medium-and large-sized arteries, which is associated with the interactions between endothelial cells, vascular smooth muscle cells, macrophages, platelets and cytokines (1). Endothelial dysfunction and inflammation are early markers of atherosclerosis (2). Normally, endothelial cells prevent interaction between vascular muscle cells and circulating monocytes and lymphocytes (3). Oxidative stress and inflammation may injure endothelial cells and promote the development of atherosclerosis (4). The damaged endothelial cells synthesize and release pro-inflammatory factors, including intercellular adhesion molecule-1 (ICAM-1) and vascular cell adhesion molecule-1 (VCAM-1), which stimulate the inflammatory cells to attach at the dysfunctional endothelial cells $(5,6)$. Therefore, protecting endothelial function is an important therapeutic strategy for the prevention of atherosclerosis.

MicroRNAs (miRNA/miR) are small, noncoding RNAs, that negatively regulate target gene expression at the post-transcriptional level by directly binding at 3'-untranslated regions (UTRs) (7). It was demonstrated previously that miRNAs may participate in the development of atherosclerosis $(8,9)$. For example, the miR-17-92 cluster was significantly downregulated among patients with atherosclerosis (10). miR-181b and miR-18a were demonstrated to inhibit endothelial inflammatory responses by targeting nuclear factor kappa-light-chain-enhancer of activated B cells signaling in 
acute and chronic vascular disease states $(8,11,12)$. miR-21 suppressed the apoptosis and death of vascular smooth muscle cell induced by hydrogen peroxide $\left(\mathrm{H}_{2} \mathrm{O}_{2}\right)$ via regulating programmed cell death 4 (13). miR-429 promoted endothelial cell apoptosis in high-fat diet mice through suppressing B-cell lymphoma 2 (Bcl-2) expression (14).

miR-291b-3p is a member of the miR-290 cluster. It was demonstrated that miR-291b-3p promoted hepatocyte apoptosis via the downregulation of RNA-binding protein $\mathrm{Hu}$ antigen R (HuR) (15). Additionally, miR-291b-3p may also regulate the metabolism of lipids and glucose in the liver via targeting adenosine monophosphate-activated kinase $\alpha 1$ and transcription factor p65 $(16,17)$. However, it remains unclear whether the miR-291b-3p is associated with endothelial dysfunction. Therefore, the present study explored the role of miR-291b-3p in endothelial dysfunction. The present study demonstrated that the treatment of $\mathrm{H}_{2} \mathrm{O}_{2}$ induced the apoptosis and increased the mRNA levels of miR-291b-3p, ICAM-1 and VCAM-1 in EOMA cells. And overexpression of miR-291b-3p promoted EOMA cell apoptosis and dysfunction. In addition, HuR was identified as a target gene of miR-291b-3p in EOMA cells. The overexpression of HuR reversed the endothelial dysfunction induced by an miR-291b-3p mimic. It was hypothesized that miR-291b-3p may be involved in the endothelial cell dysfunction induced by $\mathrm{H}_{2} \mathrm{O}_{2}$ via targeting $\mathrm{HuR}$.

\section{Materials and methods}

Cell culture. The EOMA mouse endothelial cell line (American Type Culture Collection, Manassas, VA, USA) was cultured in high-glucose Dulbecco's modified Eagle's medium (H-DMEM; Invitrogen; Thermo Fisher Scientific, Inc., Waltham, MA, USA) supplemented with $10 \%$ fetal calf serum (HyClone; GE Healthcare Life Sciences, Logan, UT, USA), 100 units/ml penicillin (Invitrogen; Thermo Fisher Scientific, Inc.) and $0.1 \mathrm{mg} / \mathrm{ml}$ streptomycin (HyClone; GE Healthcare Life Sciences) at $37^{\circ} \mathrm{C}$ with humidified air and $5 \% \mathrm{CO}_{2}$. EOMA cells were treated with $100 \mu \mathrm{M} \mathrm{H}_{2} \mathrm{O}_{2}$ (Sigma-Aldrich; Merck KGaA, Darmstadt, Germany) at $37^{\circ} \mathrm{C}$ for $24 \mathrm{~h}$.

Transfection of miR-291b-3p mimics and inhibitors in EOMA cells. The sequences of negative control (NC), microRNA inhibitor negative control (NCI), miR-291b-3p mimic (291m) and inhibitor (291i) were as follows (5'-3'): NC sense, UUC UCCGAACGUGUCACGUTT; NC antisense, ACGUGACAC GUUCGGAGAATT; NCI, CAGUACUUUUGUGUAGUA CAA; $291 \mathrm{~m}$ sense, AAAGUGCAUCCAUUUUGUUUGU; 291m antisense, AAACAAAAUGGAUGCACUUUUU; and 291i, ACAAACAAAAUGGAUGCACUUU. All the siRNA oligos were purchased from Shanghai GenePharma Co., Ltd, Shanghai, China). According to the manufacturer's protocol of HiperFect transfection reagent (Qiagen, $\mathrm{GmbH}$, Hilden, Germany), EOMA cells were seeded in 6-well plates with $1 \times 10^{5}$ cell/well with $2 \mathrm{ml} \mathrm{H}$-DMEM medium containing serum and antibiotics prior to transfection. $5 \mu 120 \mu \mathrm{M} \mathrm{NC}$, NCI, $291 \mathrm{~m}$ or $291 \mathrm{i}$ sequences were pre-incubated with HiperFect transfection reagent at room temperature for $10 \mathrm{~min}$. Then, the solutions were added into the EOMA cells at a final concentration of $50 \mathrm{nM}$. The cells were then cultured at $37^{\circ} \mathrm{C}$ for an additional $48 \mathrm{~h}$.
Adenovirus construction. Recombinant adenovirus vectors expressing mouse HuR (AD-HUR) and control adenovirus vectors containing green fluorescent protein (GFP) (AD-CON) were purchased from Shanghai GeneChem Co.,Ltd. (Shanghai, China). A total of $15 \mu \mathrm{l}$ AD-HuR $\left(1 \times 10^{10} \mathrm{pfu} / \mathrm{ml}\right)$ was transfected into EOMA cells at a multiplicity of infection of 100 for $48 \mathrm{~h}$ at $37^{\circ} \mathrm{C}$. A total of $15 \mu 1 \mathrm{AD}-\mathrm{CON}\left(1 \times 10^{10} \mathrm{pfu} / \mathrm{ml}\right)$ was added to the control groups at a multiplicity of infection of 100 to maintain a consistent viral load.

$R N A$ isolation and reverse transcription quantitative polymerase chain reaction ( $R T-q P C R)$. Total RNA was harvested from EOMA cells using TRIzol ${ }^{\circledR}$ reagent (Life Technologies; Thermo Fisher Scientific, Inc.) according to the manufacturer's protocols. A stem-loop reverse transcription primer and avian myeloblastosis virus transcriptase (Takara Biotechnology Co., Ltd., Dalian, China) were used to quantify mature miRNAs. A total of $1 \mu \mathrm{g}$ RNA was reversed transcribed into first-strand cDNA using random primers (Takara Biotechnology Co., Ltd.). qPCR was performed to determine the mRNA levels of miR-291b-3p, VCAM-1, ICAM-1 and HuR. The relative gene expression was normalized to U6 or 18s. Each reaction was performed in triplicate, and analysis was performed by the $2^{-\Delta \Delta \mathrm{Cq}}$ method (18). The relative level of miR-291b-3p was normalized by U6 small nucleolar RNA, which was used as the housekeeping gene. The sequences of RT primers were as follows (5'-3'): miR-291b-3p, GTCGTATCC AGTGCAGGGTCCGAGGTATTCGCACTGGATACGACA CAAAC; U6, GTCGTATCCAGTGCAGGGTCCGAGGTA TTCGCACTGGATACGACAAATATG. The primers used for the qPCR were as follows (5'-3'): miR-291b-3p forward, GCA AAGTGCATCCATTTTGTTTGT; U6 forward, GCGCGT CGTGAAGCGTTC; Universal reverse primer, GTGCAG GGTCCGAGGT; VCAM-1 forward, CTCTTACCTGTGCGC TGTGA; VCAM-1 reverse, GACAGGTCTCCCATGCACAA; ICAM-1 forward, TTTTCAGCTCCGGTCCTGAC; ICAM-1 reverse, CCGCTCAGAAGAACCACCTT; 18s forward, GGA AGGGCACCACCAGGAGT; and 18s reverse, TGCAGCCCC GGACATCTAAG.

Western blot analysis. Western blot analysis was performed as previously described (17). The cells were lysed with radioimmunoprecipitation assay lysis buffer (Beijing Solarbio Science and Technology Co., Ltd., Beijing, China) containing a protease inhibitor cocktail (Sigma-Aldrich; Merck KGaA) and phosphatase inhibitor cocktail (Sigma-Aldrich; Merck $\mathrm{KGaA}$ ). Following centrifugation at $10,000 \mathrm{x}$ g for $15 \mathrm{~min}$ at $4^{\circ} \mathrm{C}$, the supernatants were collected. The proteins were quantified using a bicinchoninic acid kit (Thermo Fisher Scientific, Inc.). Cell lysates containing $15 \mu \mathrm{g}$ protein were separated by $12 \%$ SDS-PAGE and transferred to polyvinylidene fluoride membranes (EMD Millipore, Billerica, MA, USA). The membranes were blocked with 5\% non-fat dry milk in TBS with Tween-20 (pH 8.0) (Beijing Solarbio Science and Technology, Co., Ltd.) and probed with the primary antibodies $(1: 1,000)$ at $4^{\circ} \mathrm{C}$ overnight. Then, the blots were incubated with horseradish peroxidase-conjugated anti-rabbit IgG secondary antibody (cat. no. ABCA2103366; Ab-mart, Inc., Berkeley Heights, NJ, USA) for $2 \mathrm{~h}$ at room temperature, followed by detection with a Immobilon 
A

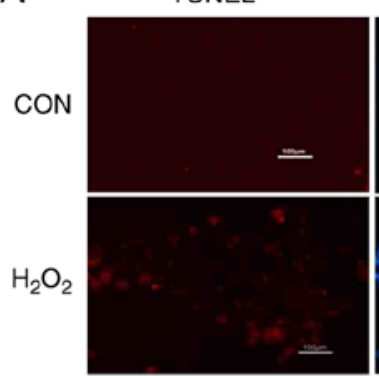

DAPI

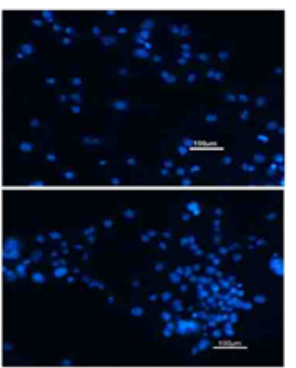

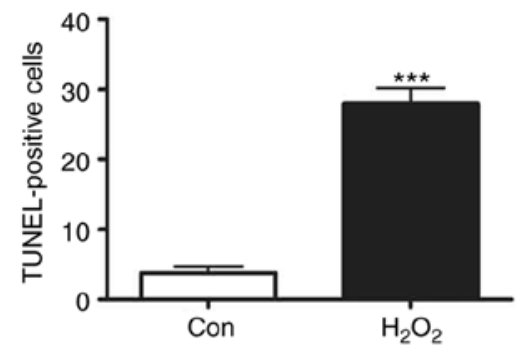

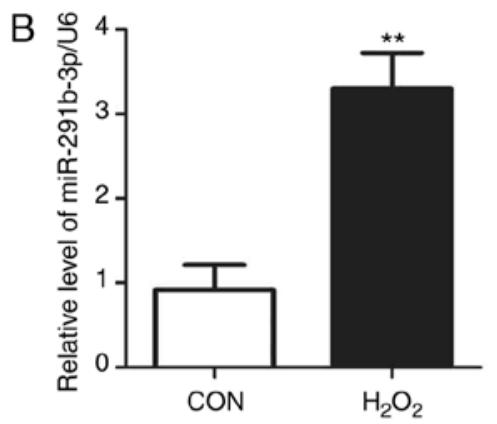

C
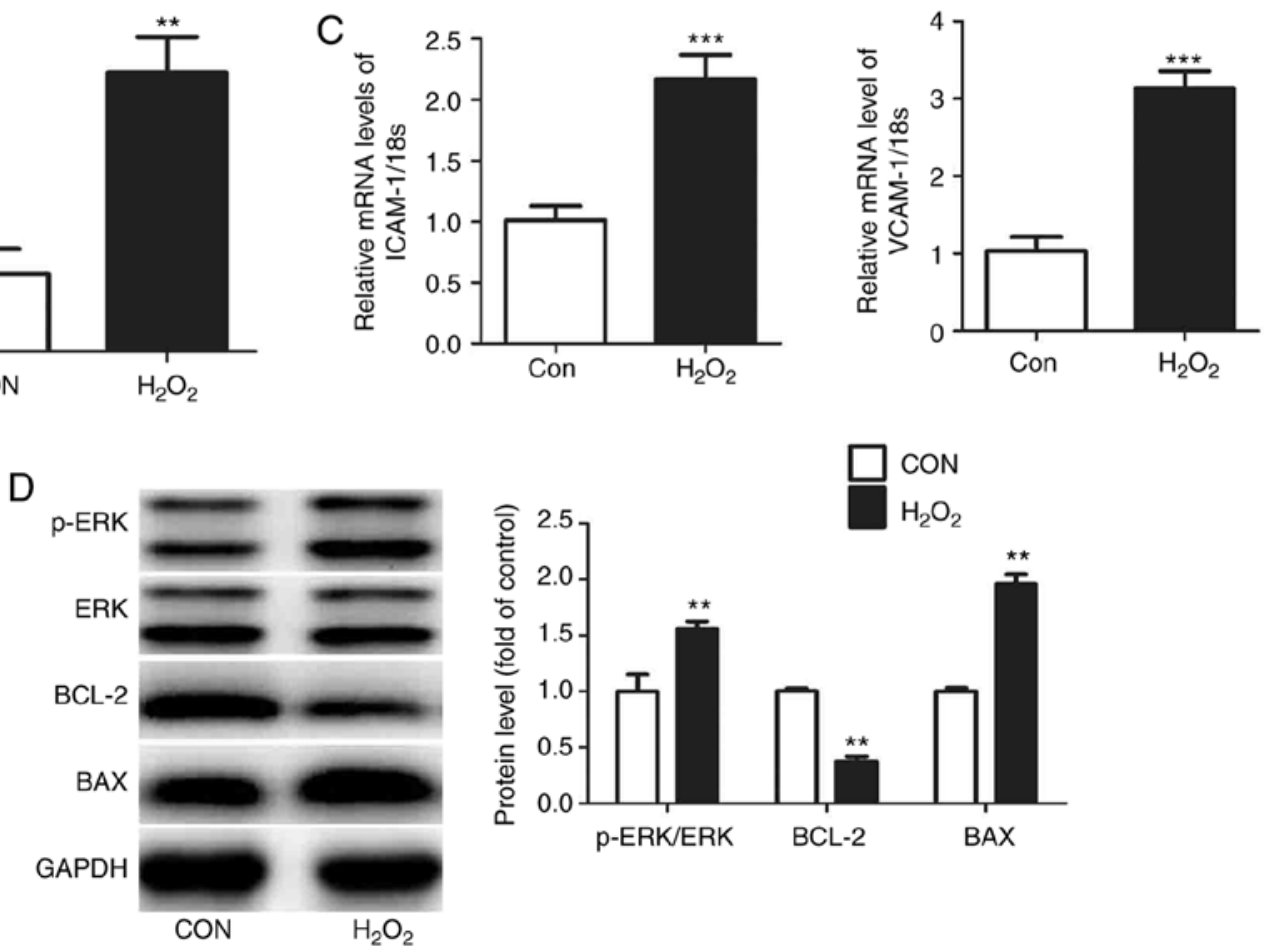

Figure $1 . \mathrm{H}_{2} \mathrm{O}_{2}$ promotes miR-291b-3p expression and apoptosis in EOMA endothelial cells. (A) The levels of apoptosis in EOMA cells treated with $\mathrm{H}_{2} \mathrm{O}_{2}$ was measured by TUNEL staining. (B) The mRNA levels of miR-291b-3p and (C) ICAM-1 and VCAM-1 were measured by quantitative polymerase chain reaction. (D) The phosphorylation of ERK and Bax and Bcl-2 expression were analyzed by western blot analysis. Data are presented as the mean \pm standard error of the mean $(\mathrm{n}=5)$. ${ }^{* *} \mathrm{P}<0.01$ and ${ }^{* * *} \mathrm{P}<0.001$ vs. control. CON, control; TUNEL, terminal deoxynucleotidyl-transferase-mediated dUTP nick end labelling; miR, microRNA; NCI, microRNA inhibitor negative control; 291m, miR-291b-3p mimic; 291i, miR-291b-3p inhibitor; ICAM-1, intercellular adhesion molecule-1; VCAM-1, vascular cell adhesion molecule-1; ERK, extracellular signal-regulated kinase; p-ERK, phosphorylated ERK; Bcl-2, B-cell lymphoma 2; Bax, Bcl-2-associated $\mathrm{X}$ protein; $\mathrm{H}_{2} \mathrm{O}_{2}$, hydrogen peroxide.

Western chemiluminescence kit (EMD Millipore). The antibodies against HuR (cat. no. 12582), Bcl-2 (cat. no. 3498, Bcl-2-associated X protein (Bax; cat. no. 5023), GAPDH (cat. no. 5174), phosphorylated extracellular signal-regulated kinase (p-ERK)1/2 (p42/44; cat. no. 4370), ERK1/2 (cat. no. 4695) and GAPDH were purchased from Cell Signaling Technology, Inc., (Danvers, MA, USA). Image J version 1.42 (National Institutes of Health, Bethesda, MD, USA) was used to calculated the band intensity.

Luciferase assay. To determine the target gene of miR-291b-3p, the 3'-UTR and coding region of HuR containing miR-291b-3p binding sites were amplified from NCTC 1469 cells (America Type Culture Collection, Manassas, VA, USA) by the following primers (restriction sites are underlined): HuR-coding region-F-XhoI: 5'-CCCTCGAGCTGGCTCTGGAATCAT TGCT-3'; HuR-coding region-R-XhoI: 5'-CCCTCGAGAGGC
AGTCTTCGGTTCTTGA-3'; HuR-UTR-F-XhoI: 5'-CCCTCG AGCCTATATGGGGTTGCTTCCA-3'; HuR-UTR-R-XhoI: 5'-CCCTCGAGCCAACCAGCCTTCTTTTCTG-3'.

PCR was performed with genomic DNA isolated from EOMA cells. The thermocycler conditions for PCR were as follows: $95^{\circ} \mathrm{C}$ for $10 \mathrm{~min}$, followed by 40 cycles of $95^{\circ} \mathrm{C}$ for $15 \mathrm{sec}, 55^{\circ} \mathrm{C}$ for $45 \mathrm{sec}$ and $72^{\circ} \mathrm{C}$ for $30 \mathrm{sec}$. A total of $2 \mu \mathrm{g}$ PCR products were digested with $1 \mu \mathrm{l}$ XhoI (New England Biolabs. Inc., Ipswich, MA, USA) and inserted into XhoI-linearlized luciferase reporter vector pmirGLO (Promega Corporation, Madison, WI, USA). To perform the luciferase reporter assay, EOMA cells were cultured in 96-well plates at 5,000 cells/well in $100 \mu \mathrm{l}$ H-DMEM culture medium. The luciferase reporter plasmid was pmirGLO from Promega Corporation. Subsequently, the recombinant luciferase vector $(0.1 \mu \mathrm{g})$ and $\mathrm{miR}-291 \mathrm{~b}-3 \mathrm{p}$ mimic $(5 \mathrm{ng})$ were transfected into EOMA cells with Effectene reagent (Qiagen 
$\mathrm{GmbH}$ ) for $48 \mathrm{~h}$. A dual-luciferase reporter assay system (Promega Corporation) was subsequently used to detect the luciferase activity of cells. Luciferase activity was normalized to Renilla luciferase activity. A total of 6 samples were measured for each group. The experiment was repeated three times.

Terminal deoxynucleotidyl-transferase-mediated dUTP nick end labelling (TUNEL) staining. TUNEL staining was used to detect DNA fragmentation of individual cells using a TUNEL fluorescence fluorescent isothiocyanate kit (Roche Diagnostics $\mathrm{GmbH}$, Mannheim, Germany). EOMA cells were fixed with $4 \%$ paraformaldehyde (Beijing Solarbio Science and Technology, Co., Ltd.) for $20 \mathrm{~min}$ at $37^{\circ} \mathrm{C}$ followed by permeabilization with $0.1 \%$ Triton X-100 (Sigma-Aldrich; Merck KGaA). Then, cells were incubated with TUNEL reaction mixture at $37^{\circ} \mathrm{C}$ for $1 \mathrm{~h}$. The nuclei were counterstained by DAPI $(1 \mu \mathrm{g} / \mathrm{ml})$ at room temperature for $10 \mathrm{~min}$. And the slide was mounted by using ProLong Diamond Antifade Mountant (Invitrogen; Thermo Fisher Scientific, Inc.). Cells in 10 randomly chosen fields from each cultured cell slide were counted to determine the percentage of apoptotic nuclei. The experiment was repeated for 4 times. The stained cells were examined using a fluorescence microscope (magnification, x200; Olympus Corporation, Tokyo, Japan).

Statistical analysis. Data were expressed as the mean \pm standard error of the mean. The two-tailed unpaired Student's t-test was used for comparisons of two groups. And one-way analysis of variance tests followed by Turkey post hoc test were performed for comparison of two more groups by using SPSS 3.0 (SPSS, Inc., Chicago, USA). $\mathrm{P}<0.05$ were considered to indicate a statistically significant difference.

\section{Results}

$\mathrm{H}_{2} \mathrm{O}_{2}$ promotes miR-291b-3p expression and apoptosis in EOMA endothelial cells. It has been confirmed that $\mathrm{H}_{2} \mathrm{O}_{2}$ induces endothelial cell apoptosis (19). To investigate the effects of miR-291b-3p on endothelial cell apoptosis, the level of miR-291b-3p was determined in the EOMA cells treated with $100 \mu \mathrm{M} \mathrm{H}_{2} \mathrm{O}_{2}$ for $24 \mathrm{~h}$. TUNEL staining confirmed that $\mathrm{H}_{2} \mathrm{O}_{2}$ treatment led to induced apoptosis in EOMA cells (Fig. 1A). Compared with the control group, the mRNA levels of miR-291b-3p, ICAM-1 and VCAM-1 were increased in EOMA cells treated with $\mathrm{H}_{2} \mathrm{O}_{2}$ (Fig. $1 \mathrm{~B}$ and C). Additionally, $\mathrm{H}_{2} \mathrm{O}_{2}$ treatment induced the phosphorylation of ERK and upregulated Bax expression, accompanied by decreased Bcl-2 protein expression (Fig. 1D). These results suggested that miR-291b-3p may be involved in the process of endothelial cell injury.

miR-291b-3p modulates endothelial cell dysfunction. Next, the effects of miR-291b-3p on EOMA cell dysfunction were observed. $291 \mathrm{~m}$ and $291 \mathrm{i}$ were transfected into EOMA cells for $48 \mathrm{~h}$. The results of the qPCR assay indicated that the level of miR-291b-3p was increased significantly in EOMA cells transfected with $291 \mathrm{~m}$ compared with those transfected with miRNA mimic controls (Fig. 2A). Overexpression of miR-291b-3p induced apoptosis and upregulated ICAM-1 and VCAM-1 mRNA expression levels in EOMA cells (Fig. 2B and C). In EOMA cells transfected with miR-291b-3p mimics, the levels of p-ERK and Bax proteins were increased, whilst Bcl-2 protein expression was decreased (Fig. 2D). In contrast, the level of miR-291b-3p was decreased to $40-50 \%$ in EOMA cells transfected with the miR-291b-3p inhibitor compared with those transfected with the miRNA inhibitor control (Fig. 2E). Transfection with miR-291b-3p inhibitors decreased the apoptosis rate and downregulated mRNA expression levels of ICAM-1 and VCAM-1 in EOMA cells (Fig. 2F and 2G). In addition, transfection with miR-291b-3p inhibitors in EOMA cells led to decreased p-ERK and BAX protein levels, accompanied by increased Bcl-2 protein expression (Fig. 2H). The results demonstrated that miR-291b-3p may modulate apoptosis and the expression of ICAM-1 and VCAM-1 in EOMA cells.

Downregulation of miR $-291 b-3 p$ rescues $\mathrm{H}_{2} \mathrm{O}_{2}$-induced dysfunction in EOMA cells. To additionally assess the role of miR-291b-3p in $\mathrm{H}_{2} \mathrm{O}_{2}$-induced EOMA cell dysfunction, miR-291b-3p inhibitors were transfected into EOMA cells for $48 \mathrm{~h}$ followed by treatment with $\mathrm{H}_{2} \mathrm{O}_{2}$ for $24 \mathrm{~h}$. Downregulation of miR-291b-3p inhibited $\mathrm{H}_{2} \mathrm{O}_{2}$-induced apoptosis in EOMA cells (Fig. 3A). Transfection with miR-291b-3p inhibitors rescued the effect of $\mathrm{H}_{2} \mathrm{O}_{2}$ on mRNA expression of ICAM-1 and VCAM-1 (Fig. 3B). In addition, $\mathrm{H}_{2} \mathrm{O}_{2}$-induced the activation of ERK and upregulation of Bax expression was also inhibited by transfection with miR-291b-3p inhibitors (Fig. 3C). These observations indicated that miR-291b-3p may be involved in the endothelial dysfunction induced by $\mathrm{H}_{2} \mathrm{O}_{2}$.

$H u R$, as a target gene of miR-291b-3p, modulates endothelial apoptosis and dysfunction. It was demonstrated previously that HuR was a target gene of miR-291b-3p in mouse hepatocytes (15). To confirm the effect of $\mathrm{HuR}$ on $\mathrm{H}_{2} \mathrm{O}_{2}$-induced endothelial dysfunction, the HuR protein and mRNA levels in EOMA cells treated with $\mathrm{H}_{2} \mathrm{O}_{2}$ were analyzed. The results indicated that $\mathrm{H}_{2} \mathrm{O}_{2}$ treatment only decreased $\mathrm{HuR}$ protein levels but did not affect HuR mRNA levels (Fig. 4A). A previous study had suggested that miR-291b-3p contained 2 binding sites in the coding region from 902-923 bp and in 3'-UTR from 4,289-4,312 bp (15). The results of the luciferase assay indicated that the overexpression of miR-291b-3p significantly decreased the luciferase activity in EOMA cells transfected with the luciferase reporter vector containing the HuR coding region. However, the luciferase activity was only slightly decreased when the EOMA cells were co-transfected with the luciferase reporter vector containing HuR-3'-UTR and miR-291b-3p mimic (Fig. 4B). Therefore, miR-291b-3p may directly bind at the coding region of HuR from 902-923 bp. The overexpression of miR-291b-3p decreased HuR levels (Fig. 4C), whilst the downregulation of miR-291b-3p led to increased HuR levels (Fig. 4D). However, miR-291b-3p did not alter the mRNA levels of HuR (Fig. 4E). In addition, the overexpression of HuR decreased the rate of apoptosis and the mRNA expression of ICAM-1 and VCAM-1 in EOMA cells (Fig. 4F and G). In EOMA cells transfected with AD-HUR, the p-ERK and BAX levels were 


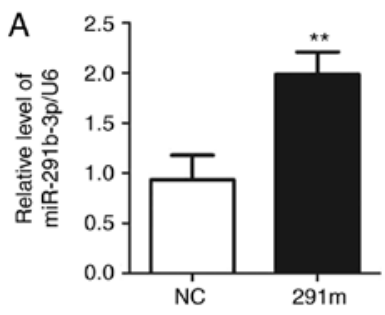

B

B TUNEL

DAPI

NC
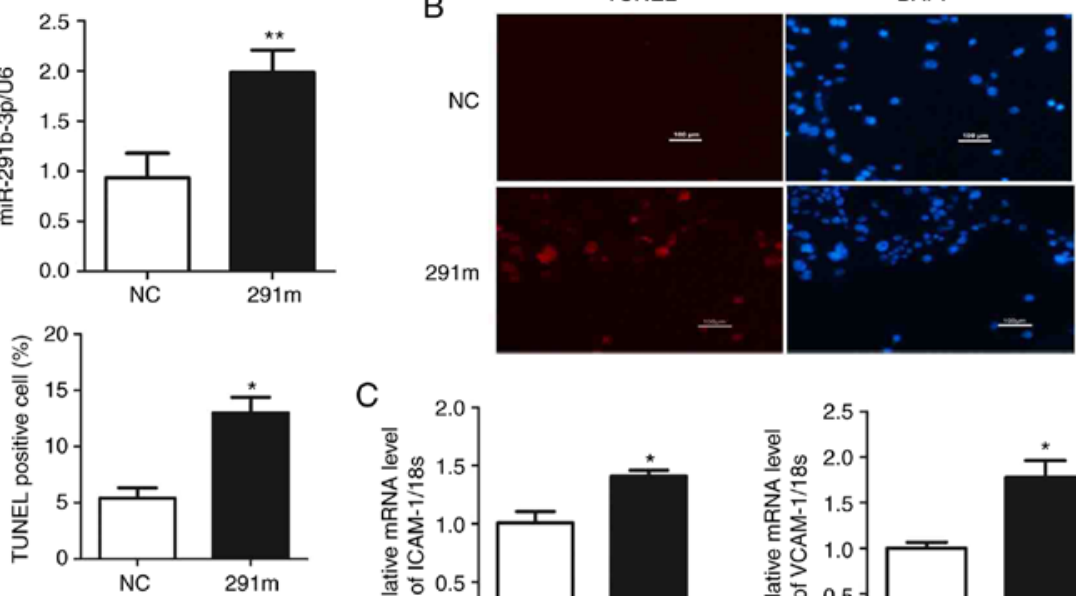

C
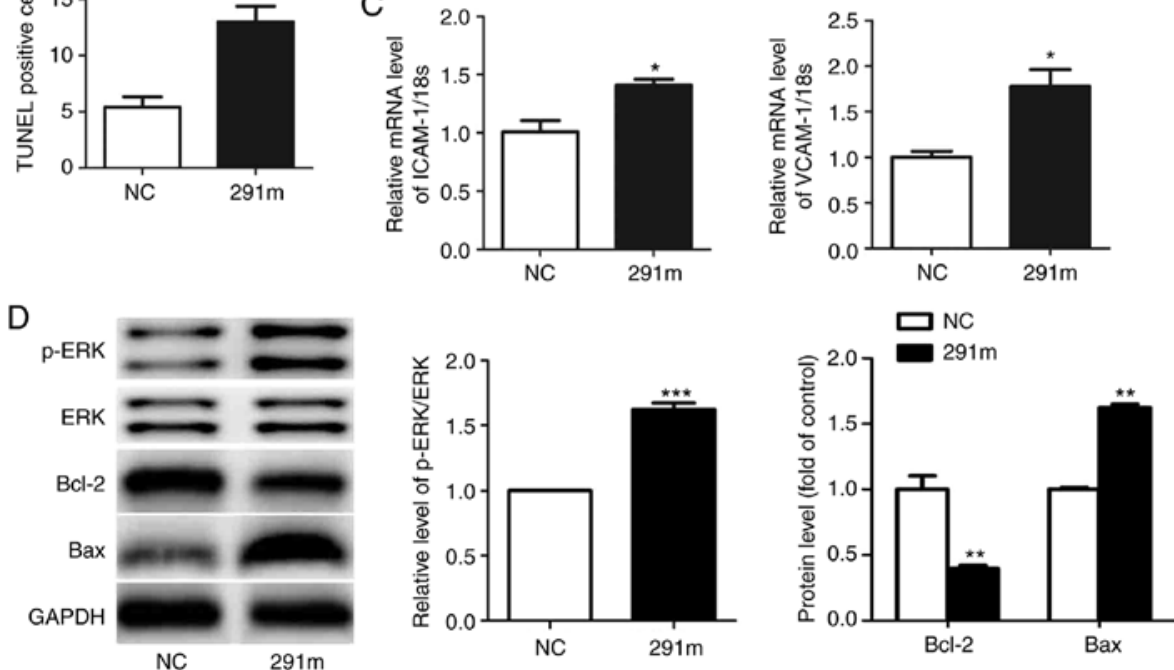

$\mathrm{F}$
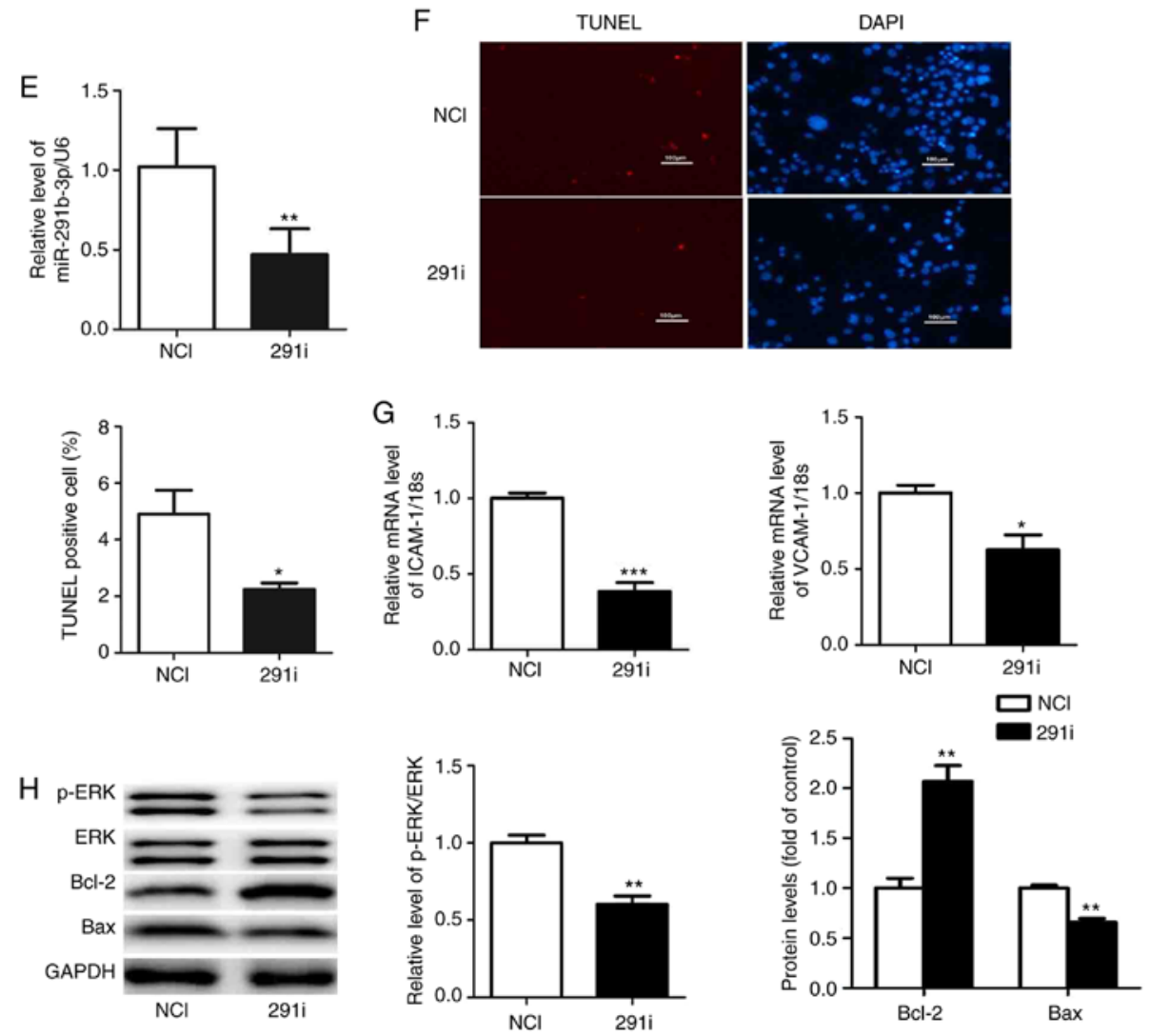

Figure 2. miR-291b-3p modulates EOMA cell dysfunction. (A) In EOMA cells, transfection with miR-291b-3p mimic increased miR-291b-3p levels and (B) cell apoptosis rate, accompanied by elevated (C) mRNA expression of ICAM-1 and VCAM-1. (D) The levels of p-ERK/ERK and Bax were raised and the protein level of Bcl2 was reduced in EOMA cells transfected with the miR-291b-3p mimic. (E) In EOMA cells, transfection with miR-291b-3p inhibitors decreased miR-291b-3p levels and (F) cell apoptosis rate, accompanied by reduced mRNA expression of (G) ICAM-1 and VCAM-1. (H) The levels of p-ERK/ERK and Bax were decreased and the protein level of Bcl2 was increased in EOMA cells transfected with miR-291b-3p mimic. Data are presented as the mean \pm standard error of the mean $(n=5) .{ }^{~} \mathrm{P}<0.05,{ }^{* *} \mathrm{P}<0.01$ and ${ }^{* * *} \mathrm{P}<0.001$ vs. the control. miR, microRNA; NC, negative control; ICAM-1, intercellular adhesion molecule-1; VCAM-1, vascular cell adhesion molecule-1; ERK, extracellular signal-regulated kinase; p-ERK, phosphorylated ERK; Bcl-2, B-cell lymphoma 2; Bax, Bcl-2-associated X protein; NCI, miRNA inhibitor negative control; 291m, miR-291b-3p mimic; 291i, miR-291b-3p inhibitor. 

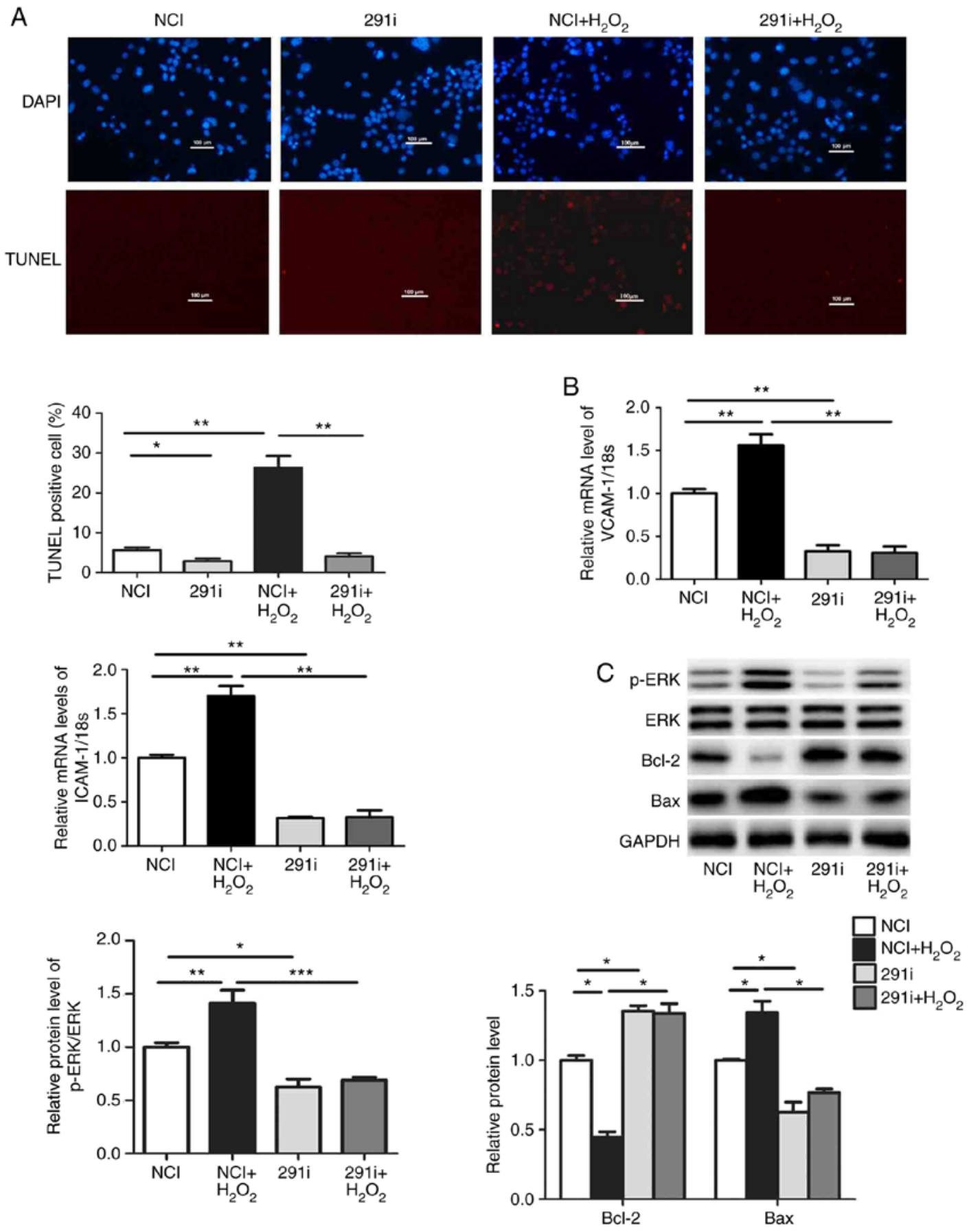

Figure 3. Downregulation of miR-291b-3p rescues $\mathrm{H}_{2} \mathrm{O}_{2}$-induced dysfunction in EOMA cells. (A) The level of apoptosis in EOMA cells transfected with miR-291b-3p inhibitor followed by treatment with $\mathrm{H}_{2} \mathrm{O}_{2}$ was measured TUNEL staining. (B) The mRNA levels of ICAM-1 and VCAM-1 were measured by quantitative polymerase chain reaction. (C) The levels of p-ERK, Bax and Bcl-2 were analyzed by western blot analysis. Data are presented as the mean \pm standard error of the mean $(\mathrm{n}=5) .{ }^{*} \mathrm{P}<0.05,{ }^{* *} \mathrm{P}<0.01$ and ${ }^{* * *} \mathrm{P}<0.001$ vs. control. TUNEL, terminal deoxynucleotidyl-transferase-mediated dUTP nick end labelling; miRNA, microRNA; NCI, miRNA inhibitor negative control; 291m, miR-291b-3p mimics; 291i, miR-291b-3p inhibitor; ICAM-1, intercellular adhesion molecule-1; VCAM-1, vascular cell adhesion molecule-1; ERK, extracellular signal-regulated kinase; p-ERK, phosphorylated ERK; Bcl-2, B-cell lymphoma 2; Bax, Bcl-2-associated X protein; $\mathrm{H}_{2} \mathrm{O}_{2}$, hydrogen peroxide.

decreased, while the Bcl-2 expression levels were increased (Fig. 4H).

miR-291b-3p regulates apoptosis and dysfunction of EOMA cells via targeting $H u R$. In order to additionally assess whether miR-291b-3p regulated EOMA cell apoptosis via targeting HuR, miR-291b-3p mimics and AD-HUR were co-transfected into EOMA cells for $48 \mathrm{~h}$. The results indicated that transfection with AD-HUR rescued the miR-291b-3p mimic-induced apoptosis and the increased mRNA expression of ICAM-1 and VCAM-1 (Fig. 5A and B). However, overexpression of miR-291b-3p did not affect the activation of ERK and the expression levels of Bax and Bcl-2 in EOMA cells transfected with AD-HUR (Fig. 5C). Taken together, these results suggested that miR-291b-3p participated in endothelial dysfunction via regulating HuR protein expression. 

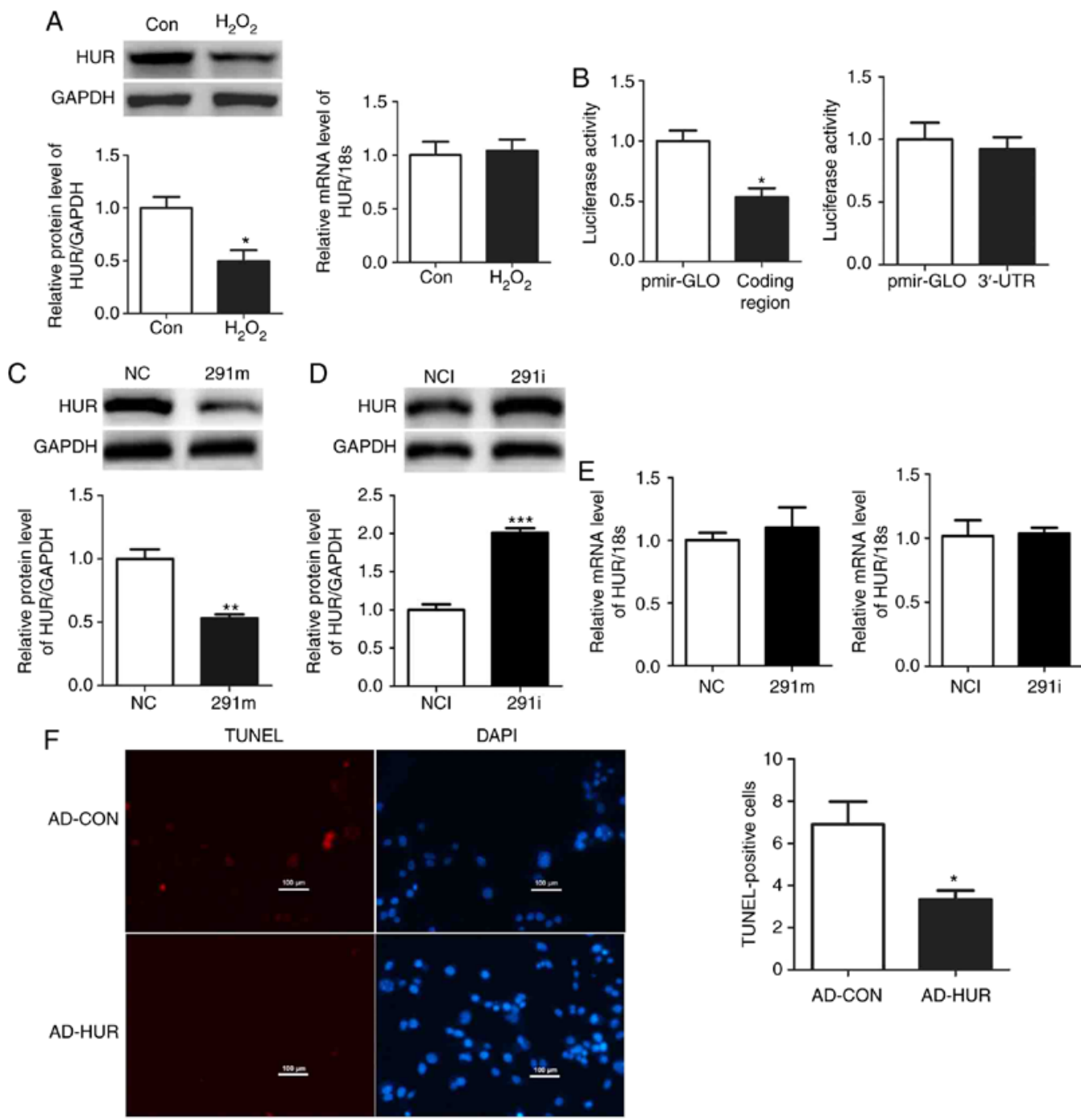

G

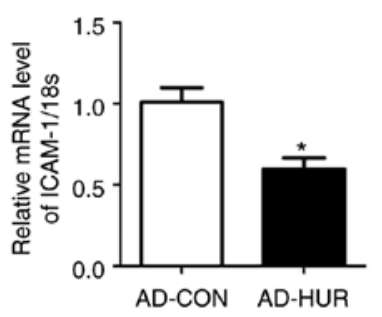

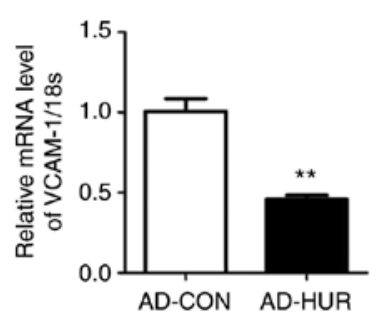

AD-CON AD-HUR
H p-ERK

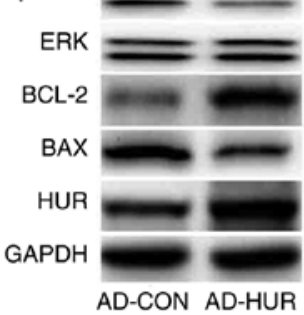

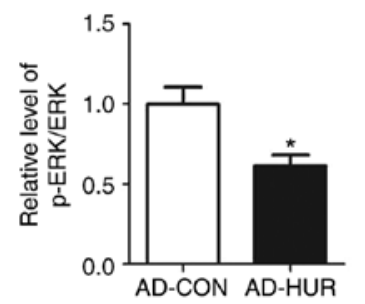
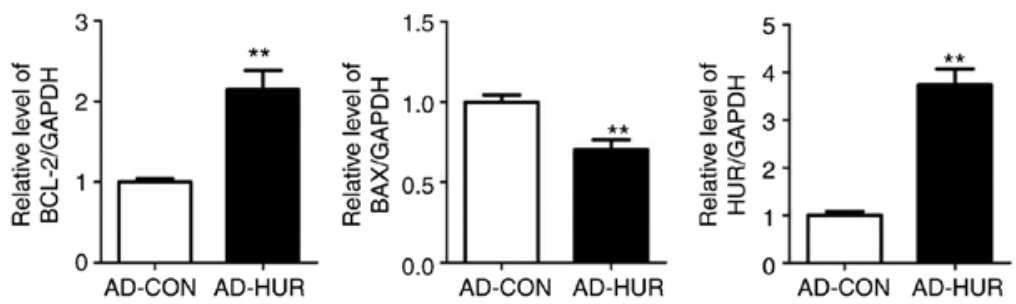

Figure 4. HuR modulated endothelial apoptosis and dysfunction. (A) The levels of HuR protein and mRNA were measured in EOMA cells treated with $\mathrm{H}_{2} \mathrm{O}_{2}$. (B) The luciferase activity was analyzed in EOMA cells transfected with luciferase reporter vector containing the HuR coding region or 3'-UTR. The protein level of HUR was analyzed in EOMA cells transfected with (C) $291 \mathrm{~m}$ or (D) 291i. (E) The mRNA level of HuR was analyzed by qPCR in EOMA cells transfected with $291 \mathrm{~m}$ or 291i. (F) The levels of apoptosis in EOMA cells transfected AD-HUR or control AD-CON vectors was measured by TUNEL staining. (G) The mRNA levels of ICAM-1 and VCAM-1 in EOMA cells transfected with AD-HUR or AD-CON were measured by qPCR. (H) The levels of p-ERK, Bax and Bcl-2 were analyzed by western blot analysis. Data are presented as the mean \pm standard error of the mean $(\mathrm{n}=5)$. ${ }^{*}<0.05,{ }^{* *} \mathrm{P}<0.01$ and ${ }^{* * *} \mathrm{P}<0.001$ vs. control. Con/NC, negative control; miRNA, microRNA; NCI, miRNA inhibitor negative control; qPCR, quantitative polymerase chain reaction; TUNEL, terminal deoxynucleotidyl-transferase-mediated dUTP nick end labelling; ICAM-1, intercellular adhesion molecule-1; VCAM-1, vascular cell adhesion molecule-1; ERK, extracellular signal-regulated kinase; p-ERK, phosphorylated ERK; Bcl-2, B-cell lymphoma 2; Bax, Bcl-2-associated X protein; HuR, $\mathrm{Hu}$ antigen $\mathrm{R}$; $\mathrm{AD}-\mathrm{CON}$, recombinant adenovirus vector expressing mouse $\mathrm{HuR} ; \mathrm{AD}-\mathrm{HUR}$, adenovirus vector containing green fluorescent protein; $\mathrm{H}_{2} \mathrm{O}_{2}$, hydrogen peroxide; 291m, miR-291b-3p mimics; 291i, miR-291b-3p inhibitor; UTR, untranslated region. 
A
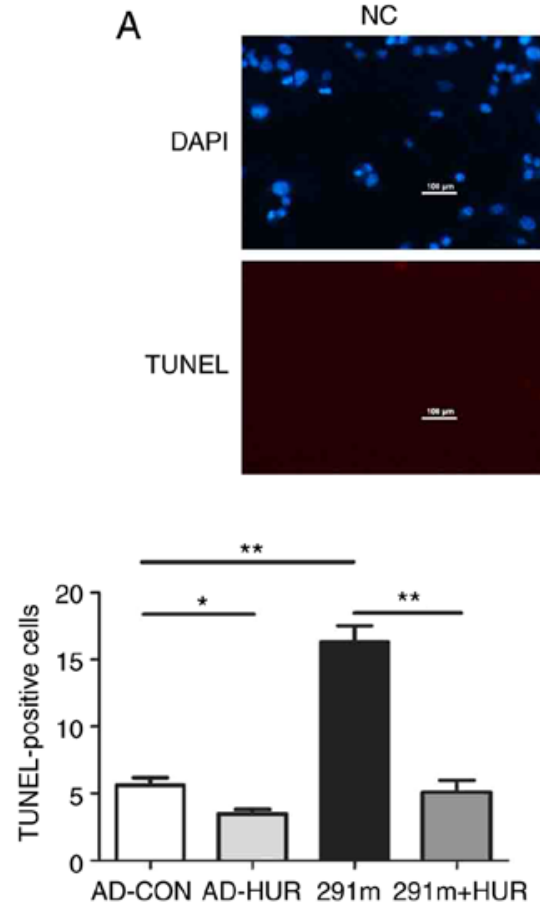

B

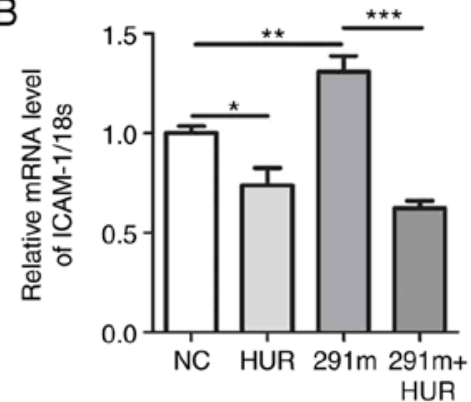

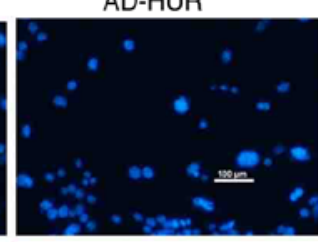

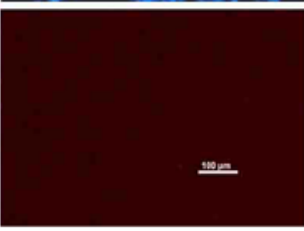

$291 \mathrm{~m}$
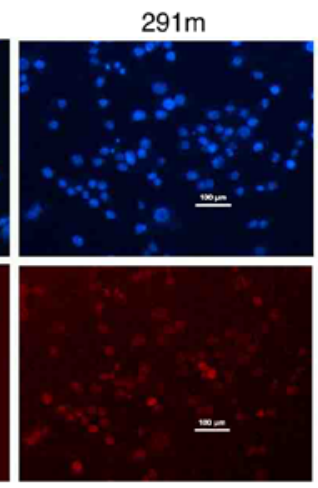

AD-HUR+291m

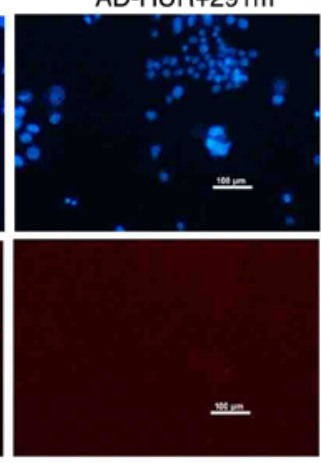

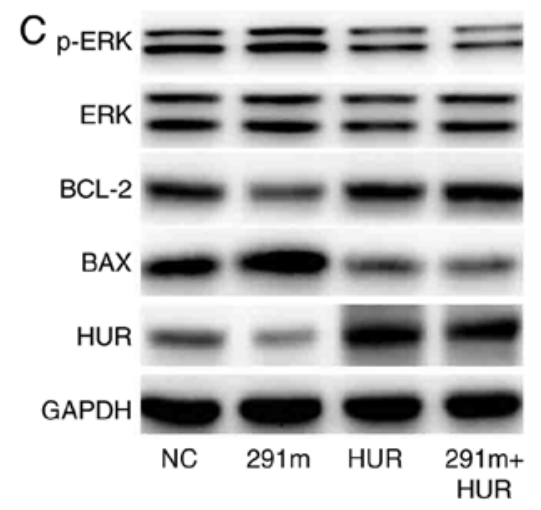
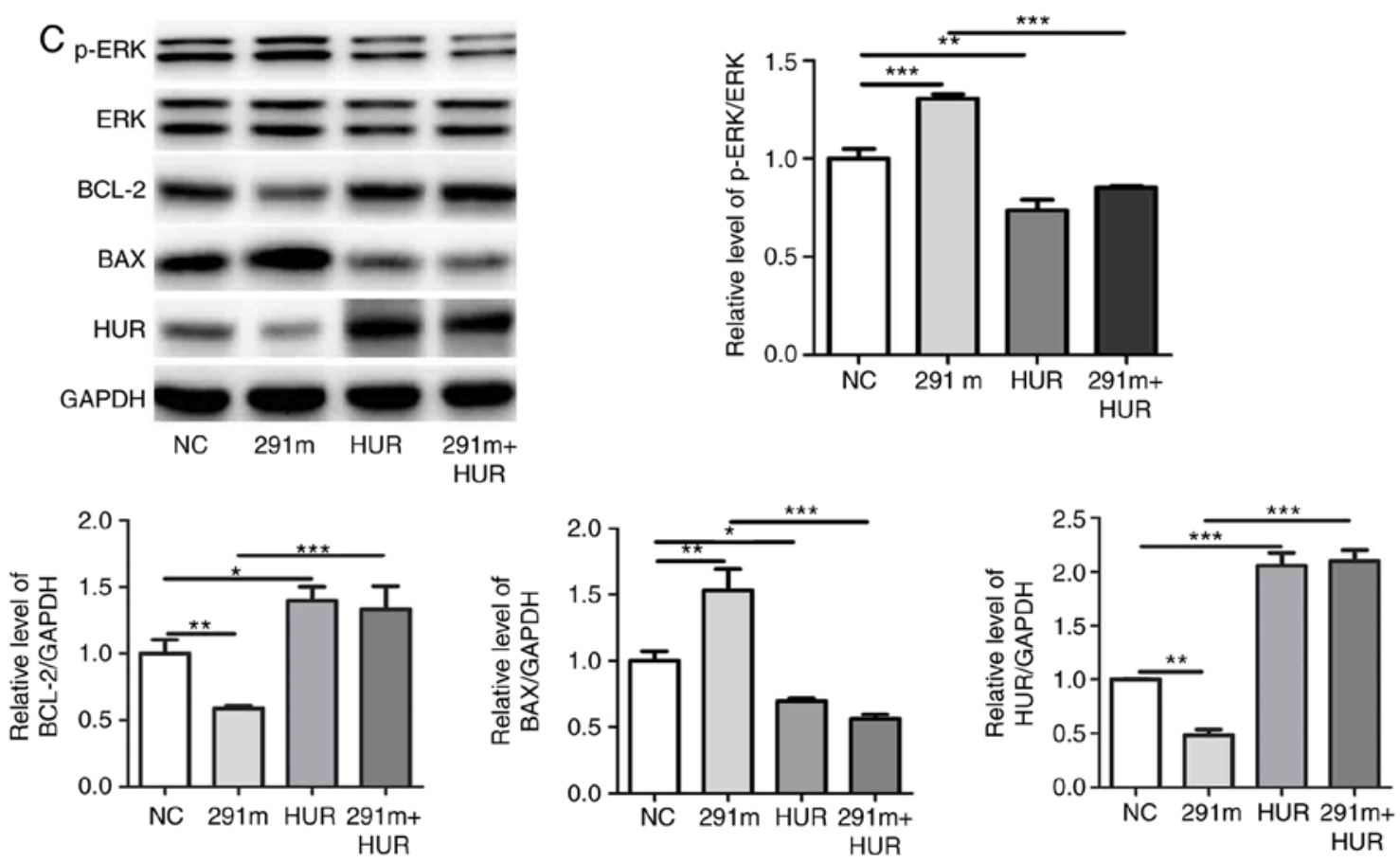

Figure 5. miR-291b-3p regulates apoptosis and dysfunction of EOMA cells via targeting HuR. (A) The levels of apoptosis in EOMA cells co-transfected with miR-291b-3p mimics and AD-HUR was measured by TUNEL staining. (B) The mRNA levels of ICAM-1 and VCAM-1 were measured by quantitative polymerase chain reaction. (C) The levels of p-ERK, Bax and Bcl-2 were analyzed by western blot analysis. Data are presented as the mean \pm standard error of the mean $(n=5) .{ }^{*} \mathrm{P}<0.05,{ }^{* *} \mathrm{P}<0.01$ and ${ }^{* * *} \mathrm{P}<0.001$ vs. control. miR, microRNA; NC, negative control; TUNEL, terminal deoxynucleotidyl-transferase-mediated dUTP nick end labelling; ICAM-1, intercellular adhesion molecule-1; VCAM-1, vascular cell adhesion molecule-1; ERK, extracellular signal-regulated kinase; p-ERK, phosphorylated ERK; Bcl-2, B-cell lymphoma 2; Bax, Bcl-2-associated X protein; NCI, miRNA inhibitor negative control; 291m, miR-291b-3p mimic; 291i, miR-291b-3p inhibitor; HuR, Hu antigen R; AD-CON, recombinant adenovirus vector expressing mouse HuR; AD-HUR, adenovirus vector containing green fluorescent protein.

\section{Discussion}

In the present study, it was demonstrated that miR-291b-3p participated in endothelial dysfunction via targeting HuR. In particular, the results indicated that: i) $\mathrm{H}_{2} \mathrm{O}_{2}$ treatment increased miR-291b-3p expression; ii) miR-291b-3p may serve an important role in endothelial dysfunction, which is involved in the $\mathrm{H}_{2} \mathrm{O}_{2}$-induced endothelial dysfunction; and iv) miR-291b-3p regulated endothelial function via targeting $\mathrm{HuR}$.

Endothelial dysfunction is a major cause of atherosclerosis. It was demonstrated that $\mathrm{H}_{2} \mathrm{O}_{2}$ damaged endothelial function by promoting cell apoptosis and inflammation (20). In the 
present study, EOMA cells were treated with $\mathrm{H}_{2} \mathrm{O}_{2}$ to establish cell models of endothelial dysfunction. In this cell model, the levels of miR-291b-3p and apoptosis were increased, accompanied by increased mRNA levels of ICAM-1 and VCAM-1.

The association between $\mathrm{H}_{2} \mathrm{O}_{2}$ and endothelial dysfunction remains incompletely characterized. Accumulating evidence has suggested that miRNAs are involved in endothelial dysfunction (21). miR-291b-3p belongs to the miR-290 cluster, which contains miR-290-3p, miR-291a-3p, miR-291b-3p, miR-292-3p, miR-294 and miR-295 (22). It was reported that mR-291b-3p may serve important roles in differentiation of embryonic stem cells, and the metabolism of lipids and glucose in the liver (15-17,23). In the present study, miR-291b-3p mimics and inhibitors were transfected into EOMA cells to additionally investigate the role of miR-291b-3p in $\mathrm{H}_{2} \mathrm{O}_{2}$-induced endothelial dysfunction. The results suggested that miR-291b-3p served as an effector molecule of $\mathrm{H}_{2} \mathrm{O}_{2}$-associated endothelial dysfunction. miR-291b-3p may modulate the protein levels of p-ERK, Bax, Bcl-2 and mRNA expression of ICAM-1 and VCAM-1 in EOMA cells. VCAM-1 and ICAM-1 are secreted by dysfunctional endothelial cells, leading to attachment of inflammatory cells to the damaged endothelial cells. The activated ERK pathway induces endothelial cells to generate excessive levels of ICAM-1 and VCAM-1, which are major factors responsible for the infiltration of inflammatory cells to the atheroma-prone sites $(5,24)$.

Next, the present study additionally identified that miR-291b-3p regulated endothelial function via targeting HuR. It was demonstrated previously that miR-291b contributed to hepatocyte apoptosis by regulating the expression of HuR, which in turn increased Bcl-2 mRNA stability (25). In the present study, it was identified that miR-291b-3p may negatively modulate HuR protein levels, and that the overexpression of HuR inhibited the effects of miR-291b-3p mimics on the endothelial functions. HuR is an RNA binding protein widely expressed in mammalian cells. AU-rich elements (AREs)-mediated transcript degradation is considered to be an important gene regulation mechanism at the post-transcriptional level (26). HuR may specifically recognize and bind to AREs to adjust mRNA stability and translation. HuR may also be transported between the nucleus and cytoplasm. This translocation allows HuR to efficiently modulate the mRNA stability (27). HuR may modulate gene expression in two distinctive mechanisms: Through one mechanism, HuR may positively regulate gene expression by stabilizing target mRNA, including cyclooxygenase-2, cyclin D1 and cyclin-dependent kinase inhibitor 1 (28-30). Through the other mechanism, HuR may also negatively modulate gene expression by decreasing the translation efficiency of mRNA, including tumor necrosis factor- $\alpha$, myc proto-oncogene protein and cyclin-dependent kinase inhibitor 1B (31-33). In a previous study, it was suggested that HuR upregulated $\mathrm{Bcl}-2$ expression by stabilizing its mRNA (15). In the present study, it was identified that the levels of p-ERK and Bax were also decreased in EOMA cells transfected with AD-HUR. However, the mechanism through which HuR regulates ERK phosphorylation, and Bax and Bcl-2 expression, requires additional study.

In conclusion, the present study provides novel data that miR-291b-3p contributes to $\mathrm{H}_{2} \mathrm{O}_{2}$-induced endothelial dysfunction via targeting HUR. The present study may provide a novel therapeutic strategy for the prevention of atherosclerosis.

\section{Acknowledgements}

Not applicable.

\section{Funding}

The present study was funded by Basic Research Project of Heilongjiang Provincial Department of Education Basic Research Project Fee (grand no. 2016-KYYWF-0593), the General Program of Heilongjiang Province Natural Science Foundation of China (grant no. H2015076), the Graduate Science and Technology Innovation Projects in Jiamusi University (grant no. YZ2016_020), the National Natural Science Foundation of China (grant nos. 81570789 and 81600618) and the Beijing Natural Science Foundation (grant no. 7182144$)$.

\section{Availability of data and materials}

The datasets used and/or analyzed during the current study are available from the corresponding author on reasonable request.

\section{Authors' contributions}

XS, SY and LD planed the experiments, XC and XL performed the cellular experiments, JY, YS and SW analyzed the data. FW and JL were involved in the study conception and design, analysis and interpretation of data, drafting and critical revision of the manuscript.

\section{Ethics approval and consent to participate}

Not applicable.

\section{Patient consent for publication}

Not applicable.

\section{Competing interests}

The authors declare that they have no competing interests.

\section{References}

1. Mannarino E and Pirro M: Molecular biology of atherosclerosis. Clin Cases Miner Bone Metab 5: 57-62, 2008.

2. Ghiadoni L, Taddei S and Virdis A: Hypertension and endothelial dysfunction: Therapeutic approach. Curr Vasc Pharmacol 10: 42-60, 2012.

3. Yung LM, Leung FP, Yao X, Chen ZY and Huang Y: Reactive oxygen species in vascular wall. Cardiovasc Hematol Disord Drug Targets 6: 1-19, 2006.

4. Baumgartner R, Forteza MJ and Ketelhuth DFJ: The interplay between cytokines and the Kynurenine pathway in inflammation and atherosclerosis. Cytokine: Sep 9, 2017 (Epub ahead of print). pii: S1043-4666(17)30259-4, 2017. doi: 10.1016/j. cyto.2017.09.004.

5. Marzolla V, Armani A, Mammi C, Moss ME, Pagliarini V, Pontecorvo L, Antelmi A, Fabbri A, Rosano G, Jaffe IZ and Caprio M: Essential role of ICAM-1 in aldosterone-induced atherosclerosis. Int J Cardiol 232: 233-242, 2017.

6. Jang YJ, Park B, Lee HW, Park HJ, Koo HJ, Kim BO, Sohn EH, Um SH and Pyo S: Sinigrin attenuates the progression of atherosclerosis in ApoE- mice fed a high-cholesterol diet potentially by inhibiting VCAM-1 expression. Chem Biol Interact 272: 28-36, 2017. 
7. Menghini R, Stohr R and Federici M: MicroRNAs in vascular aging and atherosclerosis. Ageing Res Rev 17: 68-78, 2014.

8. Feinberg MW and Moore KJ: MicroRNA regulation of atherosclerosis. Circ Res 118: 703-720, 2016

9. Karakas M, Schulte C, Appelbaum S, Ojeda F, Lackner KJ, Münzel T, Schnabel RB, Blankenberg S and Zeller T: Circulating microRNAs strongly predict cardiovascular death in patients with coronary artery disease-results from the large AtheroGene study. Eur Heart J 38: 516-523, 2017

10. Fichtlscherer S, De Rosa S, Fox H, Schwietz T, Fischer A, Liebetrau C, Weber M, Hamm CW, Röxe T, Müller-Ardogan M, et al: Circulating microRNAs in patients with coronary artery disease. Circ Res 107: 677-684, 2010.

11. Sun X, Icli B, Wara AK, Belkin N, He S, Kobzik L, Hunninghake GM, Vera MP; MICU Registry, Blackwell TS, Baron RM and Feinberg MW: MicroRNA-181b regulates NF- $\kappa$ B-mediated vascular inflammation. J Clin Invest 122 1973-1990, 2012

12. Sun X, He S, Wara AKM, Icli B, Shvartz E, Tesmenitsky Y, Belkin N, Li D, Blackwell TS, Sukhova GK, et al: Systemic delivery of microRNA-181b inhibits nuclear factor- $\kappa \mathrm{B}$ activation, vascular inflammation, and atherosclerosis in apolipoprotein E-deficient mice. Circ Res 114: 32-40, 2014.

13. Lin Y, Liu X, Cheng Y, Yang J, Huo Y and Zhang C: Involvement of MicroRNAs in hydrogen peroxide-mediated gene regulation and cellular injury response in vascular smooth muscle cells. J Biol Chem 284: 7903-7913, 2009.

14. Zhang T, Tian F, Wang J, Jing J, Zhou SS and Chen YD Atherosclerosis-associated endothelial cell apoptosis by miR-429-mediated down regulation of Bcl-2. Cell Physiol Biochem 37: 1421-1430, 2015.

15. Guo J, Li M, Meng X, Sui J, Dou L, Tang W, Huang X, Man Y, Wang S and Li J: miR-291b-3p induces apoptosis in liver cell line NCTC1469 by reducing the level of RNA-binding protein HuR. Cell Physiol Biochem 33: 810-822, 2014.

16. Meng X, Guo J, Fang W, Dou L, Li M, Huang X, Zhou S, Man Y, Tang W, Yu L and Li J: Liver MicroRNA-291b-3p promotes hepatic lipogenesis through negative Regulation of Adenosine 5'-Monophosphate (AMP)-activated protein kinase $\alpha 1$. J Biol Chem 291: 10625-10634, 2016

17. Guo J, Dou L, Meng X, Chen Z, Yang W, Fang W, Yang C, Huang X, Tang W, Yang J and Li J: Hepatic miR-291b-3p mediated glucose metabolism by directly targeting p65 to upregulate PTEN expression. Sci Rep 7: 39899, 2017.

18. Livak KJ and Schmittgen TD: Analysis of relative gene expression data using real-time quantitative PCR ad the 2(-Delta Delta $\mathrm{C}(\mathrm{T}))$ method. Methods 25: 402-408, 2001.

19. Xu MC, Gao XF, Ruan C, Ge ZR, Lu JD, Zhang JJ, Zhang Y, Wang L and Shi HM: miR-103 regulates oxidative stress by targeting the BCL2/Adenovirus E1B $19 \mathrm{kDa}$ interacting protein 3 in HUVECs. Oxid Med Cell Longev 2015: 489647, 2015.

20. Yang B, Oo TN and Rizzo V: Lipid rafts mediate $\mathrm{H} 2 \mathrm{O} 2$ prosurvival effects in cultured endothelial cells. FASEB J 20 $1501-1503,2006$
21. Watkin RL, Fitzpatrick GG and Kerrigan Sw: The evolving role of microRNAs in endothelial cell dysfunction in response to infection. Semin Thromb Hemost 44: 216-223, 2018.

22. Marson A, Levine SS, Cole MF, Frampton GM, Brambrink T, Johnstone S, Guenther MG, Johnston WK, Wernig M, Newman J, et al: Connecting microRNA genes to the core transcriptional regulatory circuitry of embryonic stem cells. Cell 134: 521-533, 2008

23. Zheng GX, Ravi A, Calabrese JM, Medeiros LA, Kirak O, Dennis LM, Jaenisch R, Burge CB and Sharp PA: A latent pro-survival function for the mir-290-295 cluster in mouse embryonic stem cells. PLoS Genet 7: e1002054, 2011.

24. Hoefen RJ and Berk BC: The role of MAP kinases in endothelial activation. Vasc Pharmacol 38: 271-273, 2002.

25. Yaman I, Fernandez J, Sarkar B, Schneider RJ, Snider MD, Nagy LE and Hatzoglou M: Nutritional control of mRNA stability is mediated by a conserved AU-rich element that binds the cytoplasmic shuttling protein HuR. J Biol Chem 277: 41539-41546, 2002.

26. Sharma S, Verma S, Vasudevan M, Samanta S, Thakur JK and Kulshreshtha R: The interplay of HuR and miR-3134 in regulation of AU rich transcriptome. RNA Biol 10: 1283-1290, 2013.

27. Chen CY, Xu N and Shyu AB: Highly selective actions of HuR in antagonizing AU-rich element-mediated mRNA destabilization. Mol Cell Biol 22: 7268-7278, 2002.

28. Wang W, Furneaux H, Cheng H, Caldwell MC, Hutter D, Liu Y, Holbrook N and Gorospe M: HuR regulates p21 mRNA stabilization by UV light. Mol Cell Biol 20: 760-769, 2000.

29. Kim GY, Lim SJ and Kim YW: Expression of HuR, COX-2, and survivin in lung cancers; cytoplasmic HuR stabilizes cyclooxygenase-2 in squamous cell carcinomas. Mod Pathol 24: 1336-1347, 2011.

30. Yuan Z, Sanders AJ, Ye L, Wang Y and Jiang WG: Knockdown of human antigen $\mathrm{R}$ reduces the growth and invasion of breast cancer cells in vitro and affects expression of cyclin D1 and MMP-9. Oncol Rep 26: 237-245, 2011.

31. Nabors LB, Suswam E, Huang Y, Yang X, Johnson MJ and King PH: Tumor necrosis factor alpha induces angiogenic factor up-regulation in malignant glioma cells: A role for RNA stabilization and HuR. Cancer Res 63: 4181-4187, 2003

32. Talwar S, Jin J, Carroll B, Liu A, Gillespie MB and Palanisamy V: Caspase-mediated cleavage of RNA-binding protein HuR regulates c-Myc protein expression after hypoxic stress. J Biol Chem 286: 32333-32343, 2011

33. Kullmann M, Göpfert U, Siewe B and Hengst L: ELAV/Hu proteins inhibit p27 translation via an IRES element in the p27 5'UTR. Genes Dev 16: 3087-3099, 2002.

This work is licensed under a Creative Common Attribution-NonCommercial-NoDerivatives 4.0 International (CC BY-NC-ND 4.0) License. 